\title{
Nonperforming Loans in Albania
}

\author{
Güngör Turan, Ph.D, \\ Department of Economics, Epoka University, Tirana, Albania \\ gturan@epoka.edu.al \\ Arjeta Koskija \\ Master Student at Banking and Finance Department, \\ Epoka University, Tirana, Albania \\ arjetakoskija@hotmail.com
}

Doi:10.5901/ajis.2014.v3n3p491

\begin{abstract}
This paper examines the continuous increase of nonperforming loans in Albania as a result of the problems caused by economics crisis and the decrease of incomes coming from emigrants. The methodology used consists on applying Johansen multivariate co-integration test to show the long-run relationship that exists between nonperforming loans and: real GDP; unemployment; inflation; loan interest rate; and remittance. The data taken are calculated on quarterly basis from 2003 to 2013. The results show that nonperforming loans and all these variables are co-integrated but this is a weak co-integration in the long run.
\end{abstract}

Keywords: Nonperforming Loans, Real GDP, Unemployment, Inflation, Loans Interest Rate, Remittance, Co-integration Test, Albania

\section{Introduction}

A boom in lending activity has characterized Albania in these last 10 years. One of the main sources that promotes economic growth for this country that has been in transition since it tear down the communism system are investments which are generally financed by crediting of banks. In this situation on one hand it can be said that the banking system is one of the most developed sectors in the country but on the other hand even though there has been an increase in the level of banking intermediation the progress that has been made is not good enough compared with the other countries and compared with the goals that the country has. The financial stability of Albania is being endangered by the increase of the overall level of the nonperforming loans. A nonperforming loan can be defined as a loan which does not provide incomes anymore because the full payment of the principal and interest is not provided, the payment may be 90 or more days late and the maturity date has passed and the payment has not been completed. Nonperforming loans cause mismatches of maturities between assets and liabilities, they decrease profitability and increase liquidity problems so their continuous increase may bring banks to insolvency.

In the first period of transition the causes of nonperforming loans were mainly related with the inefficiency of state owned banks and enterprises but now the causes of the increase of level of nonperforming loans are related with the micro and macroeconomic environmental factors where banks operate. There are two main factors that have contributed in the increase of nonperforming loans in Albania: economic crisis that directly affects GDP, unemployment and inflation of the country and the decrease of the incomes coming from emigrants. This increase of nonperforming loans shows that individuals and businesses have difficulties in making their payments and this increases the risk of the whole economic system of the country. Another factor that should be taken in consideration is that during the first years of transition the loans that were given weren't well studied. A loan register did not exist just some years ago so banks gave more than one loan to the same individual or business even though they were unable to pay it back.

What is worrying is that majority of banks believe that the level of nonperforming loans is much higher than it is reported so according to them the level of nonperforming loans will not decrease in short term. Nonperforming loans have affected more business loans than consumer loans and business loans comprise more than $70 \%$ of the total lending activity in Albania. For the business loans the most problematic ones were those ones that were given to construction companies

The study of nonperforming loans and the factors that has caused their increase is very important because in a situation where nonperforming loans are continuously increasing especially in a developing country like Albania they are 
the main obstacles of financial stability and economic growth so it is the main duty of regulators and policy makers to take immediate measures for the improvement of the situation.

After the introduction the rest of the paper consists on: section 2 literature review, section 3 data and methodology where are explained the variables and methodology used, section 4 an analysis made on the results and section 5 conclusions.

\section{Literature Review}

Recent studies especially Mwanza Nkusu (2011) has concluded that the linkages between nonperforming loans (NPL) and macroeconomic performance attributes to nonperforming loans a central role because a sharp increase of nonperforming loans cripples macroeconomic performance from several fronts. This sharp increase in NPL which weakens macroeconomic performance also activates a vicious spiral that exacerbates macro financial vulnerabilities. From another study carried out from Roland Beck, Petr Jakubik and Anamaria Piloiu (2013) was suggested that GDP growth is the main driver of nonperforming loans. Therefore a drop in global economic activity remains the most important risk for bank asset quality. At the same time, asset quality in countries with specific vulnerabilities may be negatively affected by additional factors. In particular, exchange rate depreciations might lead to an increase of nonperforming loans in countries with a high degree of lending in foreign currencies to unprotected borrowers. A drop in stock prices also negatively affects bank asset quality for example those countries with large stock markets relative to the economy. Similarly another study made by Bruna Skarica (2013) concluded that GDP is the main driver of nonperforming loans and that the high levels of NPLs are the legacy of the crisis. The results of a study made by Nir Klein (2013) showed that the level of NPLs depends on macroeconomic conditions and banks' specific factors, particularly the results showed that the increase in the level of NPLs is caused by the increases in unemployment, depreciation of exchange rate and increase of inflation. The same result that the level of NPLs depends on macroeconomic variables and banks' specific factors was found also by another study carried out by Dimitrios Angelos and Vasilios (2011) which was a study made on Greek banking system. Abdelkader Boundriga, Neila Boulila Taktak and Sana Jellouli (2014) also carried out a study to show the strong relationship that exists between nonperforming loans and bank specific variables and found out that higher capital adequacy and higher provisions are those bank specific variables that decrease the level of nonperforming loans. In Italy and Spain according to Carlos Andres and Olaya Bonilla (2012) it was concluded that macroeconomic variables are strong determinants of NPLs where the most statistically significant ones are unemployment and GDP. Another study showed that the main contributors of the increase of the level of NPLs are some factors controllable by commercial banks and they are: the diversification of funds and weak credit analysis Evelyn Richard (2011). Also for developing countries it was specifically concluded that rapid growth of nonperforming loans causes: an increase of inflation, decline of economic growth, substantial depreciation of exchange rate, high budget and balance of payment deficit influencing the banking sector with increasing interest rate and money supply which reduces the repayment capacity of borrowers Munib Badar, Atiya Yasmin Javid and Shaheed Zulfiquar (2013). This malfunctioning of the banking sector which is directly related with its inefficiency of resource allocation destroys the real economic performance of a country. The level of NPLs in India according to Krishna Prasanna (2014) depends on macroeconomic variables and moreover from his results he showed that $52 \%$ of changes in NPLs is attributed to macroeconomic variables. In Romania was found that a strong correlation exists between NPLs and unemployment rate so when unemployment increased the level of NPLs increased too, lulia luga and Ruxandra Lazea (2012). In Kenya, Daniel Kwambai and Moses Wandera 2013 have concluded that credit information sharing and level of nonperforming loans are really related to each other. Credit information sharing plays a key role because it increases transparency among financial institutions, helps the banks lend prudently, decreases the risk level to the banks, acts as a borrowers discipline against defaulting and it also reduces the borrowing cost. When the economic sectors grow, the level of lending to these sectors will also increase and in return the level of nonperforming loans tends to increase as the sector grows. The main factors that lead to bad loans in the bank are; lending to borrowers with questionable characters, serial loan defaulters, high interest rates that make it hard for some to pay back the loan, diversion of funds by borrowers. These causes make many borrowers not able to fulfill their obligations hence leading to many nonperforming loans and most of these factors are due to information asymmetry in the banking industry. Except information sharing as an important determinant of nonperforming loans in developing countries it was also concluded that corruption is an important factor that affects the level of nonperforming loans in these countries Fawad Ahmad (2013). This increase of nonperforming loans that is seen in many different countries is a very problematic issue because it leads to inefficiency of banking sector Linbo Fan,Sherill Shafer (2004) and Mohd Zain Abd Karim, Sok-Gee Chan, Sallahudin Hassan (2010). 


\section{Data and Methodology}

In this paper there are used five macroeconomic indicators to analyze the increase of nonperforming loans in Albania. These variables are: real GDP; unemployment; inflation; loan interest rate; and remittance. The data of these variables are calculated on quarterly basis from 2003 to 2013 and they are taken from quarterly reports of Bank of Albania.

Real GDP is negatively related with nonperforming loans. An overall increase of GDP brings economic development to a country so when it increases the level of NPL decreases.

Unemployment is positively related with nonperforming loans. An increase in the unemployment level means that there will be an increase in the level of people who cannot make the payments of the loans taken because of losing their jobs.

Inflation is positively related with nonperforming loans. An increase of inflation forces monetary regulators to increase interest rate to control inflation which means that there will be an increase in the cost of borrowing.

Loan interest rate is positively related with nonperforming loans because it means that the cost of borrowing will increase so people with have to pay more and they may not be able to make this payment if the loan interest rate increases.

Remittance is negatively related with nonperforming loans. A decrease in the incomes coming from emigrants causes a depreciation of home currency and those people who make the payments of their loans in dollars or euro so in foreign currency will have to pay more.

The methodology used is a multiple regression, so the model specification is:

$\mathrm{Y}=\mathrm{B} 0+\mathrm{B} 1 \mathrm{X} 1+\mathrm{B} 2 \mathrm{X} 2+\mathrm{B} 3 \mathrm{X} 3+\mathrm{B} 4 \mathrm{X} 4+\mathrm{B} 5 \mathrm{X} 5+\mathrm{U}$

Where: $Y=$ nonperforming loans

$\mathrm{B} 0=$ intercept

$\mathrm{X} 1=$ real GDP

$\mathrm{X} 2=$ unemployment

$X 3=$ inflation

$X 4=$ loan interest rate

$\mathrm{X} 5=$ remittance

$\mathrm{U}=$ random error

So NPL= B0 + B1GDP + B2UN + B3INF + B4INT + B5RE + U

Firstly all the variables are tested if they have a normally distribution. A normal distribution means a symmetric distribution and it has a bell shape with a peakness leading to a Skewness of 1 and a tail-thickness leading to a Kurtosis of 3. If the Skewness is not near to 0 and Kurtosis is not near to 3 the normality distribution is rejected. After doing this on all variables is applied Augmented Dickey Fuller unit root test meaning that all variables are examined if they have a unit root so if they are non stationary. Non stationary means that a series does not fluctuates around a mean value and does not have a tendency of coverage toward mean value. If for $1 \%, 5 \%$ and $10 \%$ level the probability is greater than 0.05 it means that the variable has a unit root (non stationary) so it is first differenced becoming stationary meaning that for $1 \%$, $5 \%$ and $10 \%$ level the probability is lower than 0.05 . The long run relationship that exists between nonperforming loans and all five other variables (real GDP, unemployment, inflation, loan interest rate, remittances) is shown by using Johansen co-integration test. If in the Johansen co-integration test the value of Trace statistic is greater than $5 \%$ critical value and if the Max-Eigen statistic is greater than $5 \%$ critical value it means that in the long run there exist a strong cointegration between nonperforming loans and: real GDP, unemployment, inflation, loan interest rate and remittances.

\section{Estimated Results}

Graph 1. Nonperforming loans, real GDP, unemployment, inflation, loan interest rate and remittance series

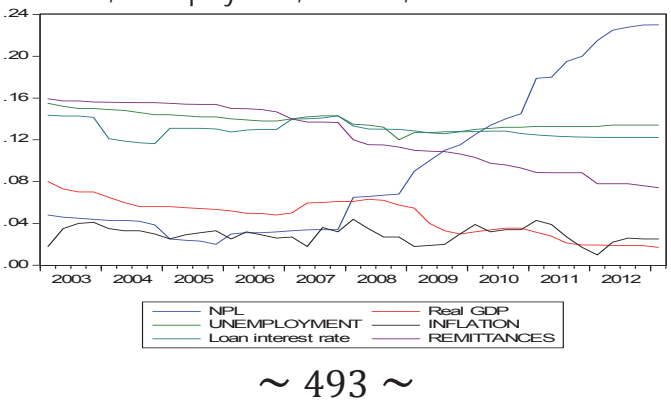


The fluctuations of these variables show the economic situation which Albania is facing, where:

1. The problems caused from the economic crisis can be easily seen in the decrease of real GDP level, in the decrease of unemployment and in the continuous changes of inflation.

2. The incomes from emigrants coming mainly from Greece and Italy also have decreased because of the economic situation that also these countries have been facing.

3. And nonperforming loans are increasing over time because of the problems caused from economic crisis, from decrease of remittances and from banks not being careful on giving loans.

Graph 2. Real GDP, unemployment, inflation, loan interest rate and remittances in Albania, scatter diagram

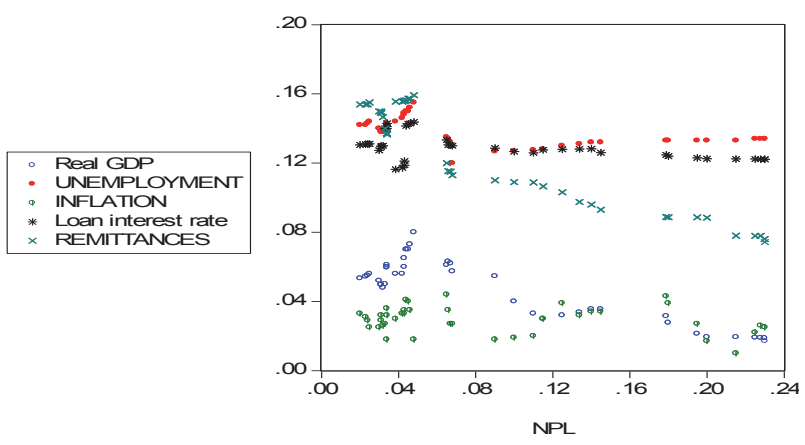

In Graph 2 when moving to the right is seen what kind of relationship nonperforming loans have with real GDP, unemployment, inflation, loan interest rate and remittances, specifically:

1. Real GDP tends to decrease nonperforming loans tend to increase.

2. Unemployment tends to increase and nonperforming loans tend to increase too.

3. Inflation tends to decrease while nonperforming loans tend to increase

4. Loan interest rate tends to decrease while nonperforming loans tend to increase

5. Remittances tend to decrease while non performing loans tend increase.

Graph 3. Histogram and statistics of nonperforming loans series

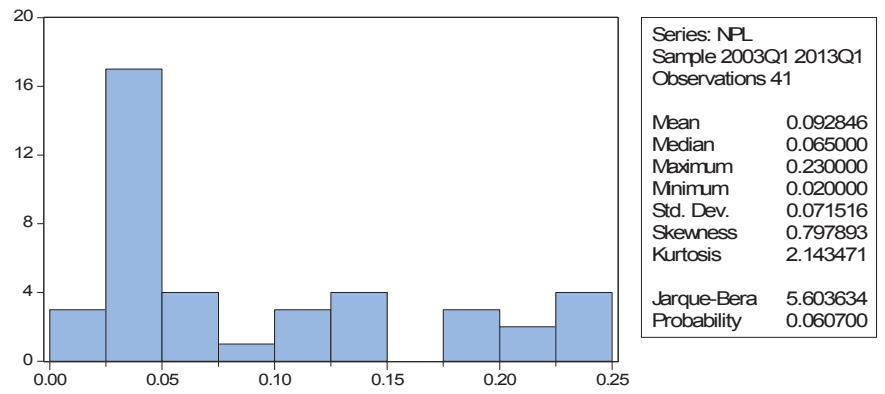

For nonperforming loans Skewness is equal to 0.797893 which is near to 0 and a Kurtosis is equal 2.143471 which is equal to 3 meaning that nonperforming loans have a normal distribution. 
Graph 4. Histogram and statistics of real GDP series
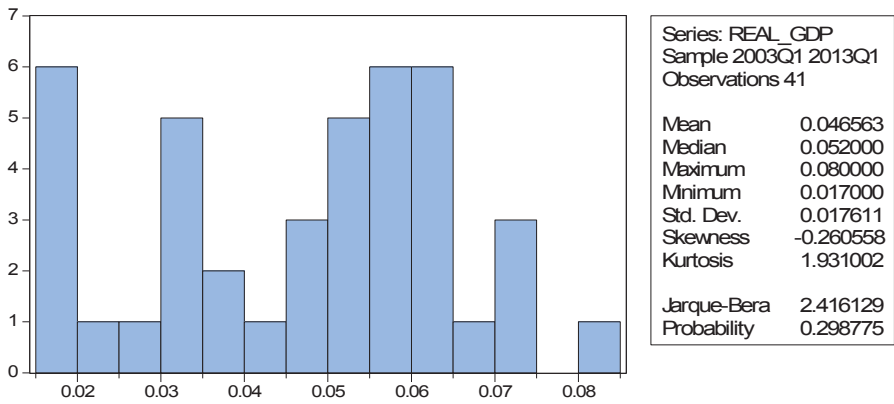

For real GDP Skewness is equal to -0.260558 which is near to 0 and Kurtosis is equal to 2.416129 which is near to 3 meaning that real GDP has a normal distribution.

Graph 5. Histogram and statistics of unemployment series
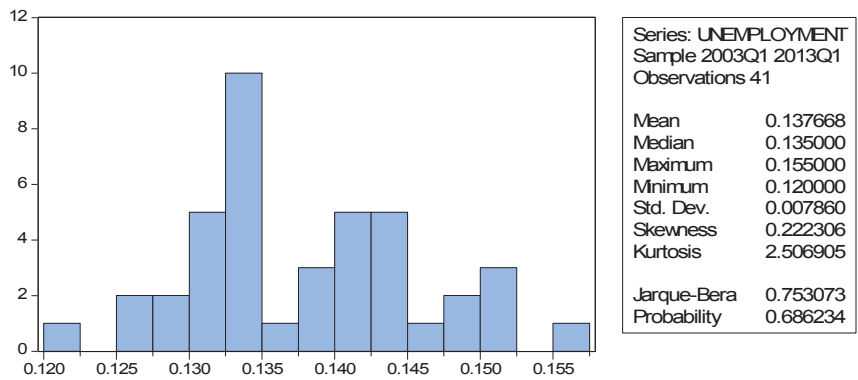

For unemployment Skewness is equal to 0.222306 which is near 0 and Kurtosis is equal to 2.506905 which is near 3 meaning that unemployment has a normal distribution.

Graph 6. Histogram and statistics of inflation series

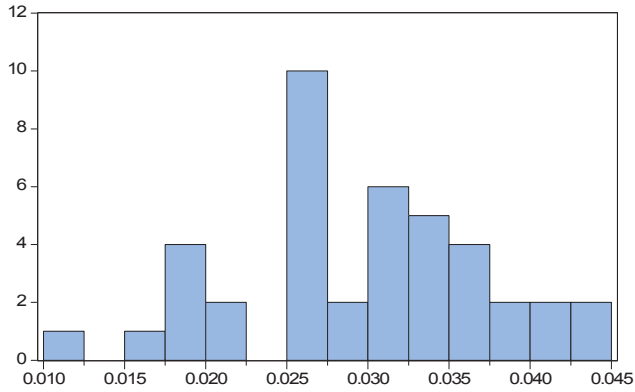

\begin{tabular}{|ll|}
\hline \multicolumn{2}{|l|}{ Series: INFLATION } \\
Sample2003Q1 2013Q1 \\
\multicolumn{2}{|l|}{ Observations 41} \\
Mean & 0.029293 \\
Median & 0.030000 \\
Maximum & 0.044000 \\
Mnimum & 0.010000 \\
Std. Dev. & 0.007692 \\
Skewness & -0.243113 \\
Kurtosis & 2.724018 \\
& \\
Jarque-Bera & 0.533994 \\
Probability & 0.765675 \\
\hline
\end{tabular}

For inflation Skewness is equal to -0.243113 which is near to 0 and Kurtosis is equal to 2.724018 which is near to 3 meaning that inflation has a normal distribution. 
Graph 7. Histogram and statistics of loan interest rate series
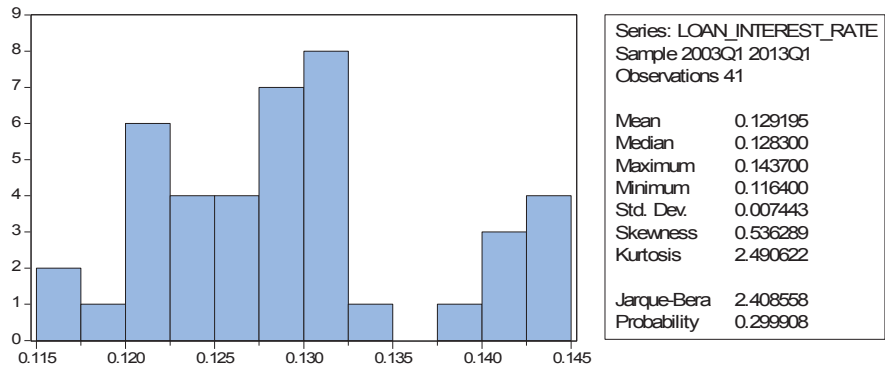

For loan interest rate Skewness is 0.536289 which is equal to 0 and Kurtosis is equal to 2.490622 which is near to 3 meaning that loan interest rate has a normal distribution.

Graph 8. Histogram and statistics of remittances series
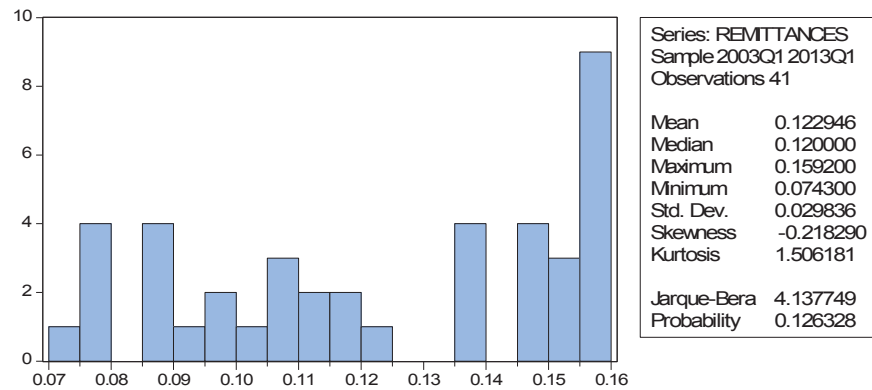

For remittance Skewness is equal to -0.218290 which is near to 0 and Kurtosis is equal to 1.506181 near 3 meaning that remittance has a normal distribution.

Table.1 Descriptive statistics of all variables

\begin{tabular}{|l|c|c|c|c|c|c|}
\hline & NPL & REAL_GDP & UNEMPLOYMENT & INFLATION & LOAN_INTEREST_RATE & REMITTANCES \\
\hline Mean & 0.092846 & 0.046563 & 0.137668 & 0.029293 & 0.129195 & 0.122946 \\
\hline Median & 0.065000 & 0.052000 & 0.135000 & 0.030000 & 0.128300 & 0.120000 \\
\hline Maximum & 0.230000 & 0.080000 & 0.155000 & 0.044000 & 0.143700 & 0.159200 \\
\hline Minimum & 0.020000 & 0.017000 & 0.120000 & 0.010000 & 0.116400 & 0.074300 \\
\hline Std. Dev. & 0.071516 & 0.017611 & 0.007860 & 0.007692 & 0.007443 & 0.029836 \\
\hline Skewness & 0.797893 & -0.260558 & 0.222306 & -0.243113 & 0.536289 & -0.218290 \\
\hline Kurtosis & 2.143471 & 1.931002 & 2.506905 & 2.724018 & 2.490622 & 1.506181 \\
\hline & & & & & & \\
\hline Jarque-Bera & 5.603634 & 2.416129 & 0.753073 & 0.533994 & 2.408558 & 4.137749 \\
\hline Probability & 0.060700 & 0.298775 & 0.686234 & 0.765675 & 0.299908 & 0.126328 \\
\hline & & & & & & 5.297000 \\
\hline Sum & 3.806700 & 1.909100 & 5.644400 & 1.201000 & & 5.040800 \\
\hline $\begin{array}{l}\text { Sum Sq. } \\
\text { Dev. }\end{array}$ & 0.204583 & 0.012406 & 0.002471 & 0.002366 & 0.002216 & 0.035607 \\
\hline & & & & & & 41 \\
\hline Observations & 41 & 41 & 41 & 41 & & \\
\hline
\end{tabular}

Table.1 shows the group statistic where for each variable is made the same analysis as in the series statistics(mean, median, maximum, minimum, Std.Dev, Skewness, kurtosis, Jarqua-Bera, probability, sum, sum Sq. Dev) and again is 
seen that all variables are normally distributed.

Table.2: Estimated Equation Output

Sample: 2003Q1 2013Q1

Included observations: 41

\begin{tabular}{lcccc}
\hline \hline \multicolumn{1}{c}{ Variable } & Coefficient & Std. Error & t-Statistic & Prob. \\
& & & & \\
\hline \hline C & 0.033834 & 0.055798 & 0.606370 & 0.5482 \\
REAL_GDP & -0.772011 & 0.253977 & -3.039689 & 0.0045 \\
UNEMPLOYMENT & 3.841085 & 0.383110 & 10.02607 & 0.0000 \\
INFLATION & -0.246298 & 0.261159 & -0.943094 & 0.3521 \\
LOAN_INTEREST_RATE & -0.911462 & 0.339569 & -2.684176 & 0.0110 \\
REMITTANCES & -2.512194 & 0.154053 & -16.30734 & 0.0000 \\
& & & \\
\hline \hline R-Squared & 0.975041 & Mean dependent var & 0.092846 \\
Adjusted R-squared & 0.971475 & S.D. dependent var & 0.071516 \\
S.E. of regression & 0.012079 & Akaike info criterion & -5.860315 \\
Sum squared resid & 0.005106 & Schwarz criterion & -5.609548 \\
Log likelihood & 126.1365 & Hannan-Quinn criter. & -5.769000 \\
F-statistic & 273.4605 & Durbin-Watson stat & 0.741452 \\
Prob(F-statistic) & 0.000000 & & \\
& & & \\
\hline \hline
\end{tabular}

In the table is noticed that when:

Real GDP increases by 1 unit NPL decreases 0.77 unit

Unemployment increases by 1 unit NPL increases 3.84 unit

Inflation increases by 1 unit NPL decreases by 0.25 unit

Loan interest rate increases by 1 unit, NPL decreases 0.91 unit

Remittances increases by 1 unit, NPL decreases by 2.51 unit.

From these results is seen that there exist a negative relationship between non performing loans and inflation and also a negative relationship between nonperforming loans and loan interest rate. These results are against the international results from which is concluded that there exists a positive relationship between nonperforming loans and these other two variables (inflation, loan interest rate).

As the equation was NPL= B0 + B1GDP + B2UN + B3INF + B4INT + B5RE + U

by substituting the values is achieved the final equation:

$\mathrm{NPL}=0.033834-0.772011 \mathrm{GDP}+3.841085 \mathrm{UN}-0.246298 \mathrm{INF}-0.911462 \mathrm{INT}-2.512194 \mathrm{RE}$

Table.3: Augmented Dickey Fuller Unit Root Test on NPL, real GDP, unemployment, inflation, loan interest rate, remittances

\begin{tabular}{|l|l|}
\hline \multicolumn{1}{|c|}{ Variables } \\
\hline NPL \\
\hline Real GDP \\
\hline Unemployment \\
\hline Inflation \\
\hline Loan interest rate \\
\hline Remittances
\end{tabular}

\begin{tabular}{|c|}
\hline $1 \%$ level \\
\hline-3.610453 \\
\hline-3.610453 \\
\hline-3.610453 \\
\hline-3.610453 \\
\hline-3.610453 \\
\hline-3.610453 \\
\hline
\end{tabular}

\begin{tabular}{|c|c|c|}
\hline $5 \%$ level & $10 \%$ level & Probability \\
\hline-2.938987 & -2.607932 & 0.9992 \\
\hline-2.938987 & -2.607932 & 0.8075 \\
\hline-2.938987 & -2.607932 & 0.2763 \\
\hline-2.938987 & -2.607932 & 0.0219 \\
\hline-2.938987 & -2.607932 & 0.0565 \\
\hline-2.938987 & -2.607932 & 0.985 \\
\hline
\end{tabular}


Table.4: Augmented Dickey Fuller Unit Root Test on D(NPL, real GDP, unemployment, inflation, loan interest rate, remittances )

\begin{tabular}{|l|c|c|c|c|}
\hline \multicolumn{1}{|c|}{ Variables } & $1 \%$ level & $5 \%$ level & $10 \%$ level & Probability \\
\hline D(NPL) & -2.625606 & -1.949609 & -1.611593 & 0.0000 \\
\hline D(Real GDP) & -2.625606 & -1.949609 & -1.611593 & 0.0005 \\
\hline D(Unemployment) & 2.625606 & 1.949609 & -1.611593 & 0 \\
\hline D(Loan interest rate) & -2.625606 & -1.949609 & -1.611593 & 0.0000 \\
\hline D(Remittances) & -2.625606 & -1.949609 & 1.611593 & 0.0001 \\
\hline
\end{tabular}

All the variables are analyzed if they have a unit root or not so if they are non stationary or stationary or in other words if they are integrated in the same order. From the results of Augmented Dickey Fuller Unit Root Test as it is seen in the table all the variables except inflation have a unit root so they are non stationary because the value of probability is greater than 0.05 but when first differenced they become stationary their probabilities are lower than 0.05 .

After converting non stationary variables into stationary ones it is applied Johansen co-integration test to see whether these variables are co-integrated in the long run.

Table.5 Johansen co-integration test

Series: NPL REAL_GDP UNEMPLOYMENT INFLATION LOAN_INTEREST_RATE REMITTANCES

Lags interval (in first differences): 1 to 2

Unrestricted Cointegration Rank Test (Trace)

\begin{tabular}{lcccc}
\hline \hline $\begin{array}{c}\text { Hypothesized } \\
\text { No. of CE(s) }\end{array}$ & Eigenvalue & $\begin{array}{c}\text { Trace } \\
\text { Statistic }\end{array}$ & $\begin{array}{c}0.05 \\
\text { Critical Value }\end{array}$ & Prob.* $^{*}$ \\
\hline \hline None * & & 117.6240 & 95.75366 & 0.0007 \\
At most 1 & 0.591094 & 83.64178 & 69.81889 & 0.0027 \\
At most 2 & 0.514157 & 56.21076 & 47.85613 & 0.0068 \\
At most 3 & 0.450358 & 33.46822 & 29.79707 & 0.0181 \\
At most 4 & 0.395210 & 14.35898 & 15.49471 & 0.0736 \\
At most 5 & 0.240533 & 3.903741 & 3.841466 & 0.0482 \\
\hline \hline
\end{tabular}

Trace test indicates 4 cointegrating eqn(s) at the 0.05 level

* denotes rejection of the hypothesis at the 0.05 level

**MacKinnon-Haug-Michelis (1999) p-values

Unrestricted Cointegration Rank Test (Maximum Eigenvalue)

\begin{tabular}{lcccc}
\hline \hline $\begin{array}{c}\text { Hypothesized } \\
\text { No. of CE(s) }\end{array}$ & Eigenvalue & $\begin{array}{c}\text { Max-Eigen } \\
\text { Statistic }\end{array}$ & $\begin{array}{c}0.05 \\
\text { Critical Value }\end{array}$ & Prob.** \\
\hline \hline & & & & \\
None & & & 40.07757 & 0.2068 \\
At most 1 & 0.591094 & 33.98226 & 33.87687 & 0.2410 \\
At most 2 & 0.514157 & 27.43102 & 27.58434 & 0.1847 \\
At most 3 & 0.450358 & 22.74254 & 21.13162 & 0.0937 \\
At most 4 & 0.395210 & 19.10924 & 14.26460 & 0.1837 \\
At most 5 & 0.240533 & 10.45523 & 3.841466 & 0.0482 \\
& 0.097629 & 3.903741 & & \\
\hline \hline
\end{tabular}

Max-eigenvalue test indicates no cointegration at the 0.05 level

* denotes rejection of the hypothesis at the 0.05 level

${ }^{* *}$ MacKinnon-Haug-Michelis (1999) p-values

In Table 5, Trace test indicates 4 co-integrating equations at the 0.05 level where the Trace statistic is greater than $5 \%$ critical value while Max-Eigen value test indicates that there is no co-integration at 0.05 level because Max-Eigen statistic 
is lower than $5 \%$ critical value. In other words nonperforming loans and the other five variables: real GDP, unemployment, inflation, loan interest rate, remittances are co-integrated to each other but in the long run this co-integration is weak.

\section{Conclusions}

Albanian banking system is facing many challenges. The problems caused by economic crisis, the decrease of incomes coming from emigrants and the fact that banks were not careful on giving loans in the first years of transition have caused a continuous increase of nonperforming loans. In this situation an analysis of the micro and macroeconomic environmental factors where banks operate must be done. There are five economic variables taken in consideration in this paper as main economic variables affecting the level of nonperforming loans and they are: real GDP, unemployment, inflation, loan interest rate and remittances. From what it is concluded from the results of Johansen co-integration nonperforming loans and the other five variables: real GDP, unemployment, inflation, loan interest rate, remittances are co-integrated to each other but in the long run this co-integration is weak.

It is important to pay more attention to this situation because when nonperforming loans increase the whole economic stability of the country is being endangered so regulators must take some fiscal and monetary measures to improve it. Even though the Albanian banking system has made a progress compared to the first years of transition there are still some other things that need to be done.

For the improvement of the situation there are some measures that can be taken:

- Start to develop a tighter loan monitoring process. Banks must be more careful than they are now when giving new loans because in this way they can improve their loans portfolio step by step.

- Lending smaller loans than larger ones.

- For large clients accept financial statements that are audited form reputable companies.

- Offer training to loan officers continuously.

\section{References}

Abdelkader Boundriga, Neila Boulila Taktak and Sana Jellouli (2014) "Does bank supervision impact nonperforming loans: crosscountry determinants using aggregate data?", http://www.researchgate.net/publication/38309279_Does_bank_supervision impact_nonperforming_loans_cross-country_determinants_using_agregate_data_

Bank of Albania quarterly reports for 2003

Bank of Albania quarterly reports for 2004

Bank of Albania quarterly reports of 2005

Bank of Albania quarterly reports of 2006

Bank of Albania quarterly reports of 2007

Bank of Albania quarterly reports of 2008

Bank of Albania quarterly reports of 2009

Bank of Albania quarterly reports of 2010

Bank of Albania quarterly reports of 2011

Bank of Albania quarterly reports of 2012

Bank of Albania quarterly reports of 2013

Bruna Skarica (2013) "Determinants of nonperforming loans in Central and Eastern European countries", http://fintp.ijf.hr/upload/files /ftp/2014/1/skarica.pdf

Carlos Andres and Olaya Bonilla (2012), "Macroeconomic determinants of Nonperforming Loans in Spain and Italy", http://www.banrepcultural.org/sites/default/files/tesis_olaya_carlos.pdf

Dimitrios Angelos and Vasilios (2011), "Macroeconomic and bank specific determinants of nonperforming loans in Greece: a comparative study of mortgage business and consumer loan portfolios", http://www.bankofgreece.gr/BogEkdoseis IPaper2010118.pdf

Evelyn Richard (2011), "Factors that cause Nonperforming Loans in Commercial Banks in Tanzia and Strategies to Resolve Them", http://www.na-businesspress.com/JMPP/RichardE_Web12_7_.pdf

Fawad Ahmad (2013), '“Corruption and Information Sharing as Determinants of Nonperforming Loans", Business System Research, Vol.4, No.1, pp.87-98

luga and Ruxandra Lazea (2012), "The influence of unemployment rate over nonperforming loans in Romania using the correlation indicator", http://oeconomica.uab.ro/upload/lucrari/1420122/18.pdf

Iva Gjergji, (2013), " An analysis of nonperforming loans in the Albanian banking system", http://www.ijbcnet.com/2-6/IJBC-13-2602.pdf

Kipyego Daniel Kwambai and Moses Wandera, ( 2013), "Effects of credit information sharing on nonperforming loans: case of Kenya", http://www.eujournal.org/index.php/esj/article/view/1048

Krishna Prasanna (2014), "Determinants of Nonperforming Loans in Indian Banking System", http://psrcentre.org/images/ 
extraimages/214306.pdf

Linbo Fan and Sherill Shafer (2004), "Efficiency versus risk in large domestic US banks", Managerial Finance, Vol. 30 Iss: 9 , pp.1 - 19

Mohd Zain Abd Karim, Sok-Gee Chan, Sallahudin Hassan (2010), " Bank Efficiency and Nonperforming Loans: Evidence from Malaysia and Singapore",http://www.researchgate.net/publication/46560594_Bank_Efficiency_And_Non-Performing _Loans_Evidence_ From_Malaysia_And_Singapore

Munib Badar and Atiya Yasmin Javid, (2013), "Impact of macroeconomic forces on nonperforming loans in Pakistan", http://www.wseas.org/multimedia/journals/economics/2013/56-259.pdf

Mwanza Nkusu, (2011), "Nonperforming loans and macrofinancial vulnerabilities in advanced economy", http://www.imf.org/external /pubs/ft/wp/2011/wp11161.pdf

Nir Klein, (2013), "Nonperforming loans in CESEE: Determinants and Impact of Macroeconomic Performance", http://papers.ssrn.com/sol3/papers.cfm?abstract_id=2247224

Roland Beck, Petr Jakubik and Anamaria Piloiu (2013), "Nonperforming loans: What matters in addition to the economic cycle?", http://papers.ssrn.com/sol3/papers.cfm?abstract_id=2214971

\section{Appendix}

\begin{tabular}{|c|c|c|c|c|c|c|}
\hline Years & NPL & Real GDP & Unemployment & Inflation & Loan interest rate & Remittance \\
\hline 2003Q1 & $4.80 \%$ & $8 \%$ & $15.50 \%$ & $1.80 \%$ & $14.37 \%$ & $15.92 \%$ \\
\hline 2003Q2 & $4.60 \%$ & $7.30 \%$ & $15.20 \%$ & $3.50 \%$ & $14.29 \%$ & $15.72 \%$ \\
\hline 2003Q3 & $4.50 \%$ & $7 \%$ & $15 \%$ & $4.00 \%$ & $14.27 \%$ & $15.72 \%$ \\
\hline $2003 Q 4$ & $4.40 \%$ & $7 \%$ & $15 \%$ & $4.10 \%$ & $14.15 \%$ & $15.62 \%$ \\
\hline 2004Q1 & $4.30 \%$ & $6.50 \%$ & $14.90 \%$ & $3.50 \%$ & $12.11 \%$ & $15.61 \%$ \\
\hline 2004Q2 & $4.30 \%$ & $6 \%$ & $14.80 \%$ & $3.30 \%$ & $11.88 \%$ & $15.57 \%$ \\
\hline 2004Q3 & $4.20 \%$ & $5.60 \%$ & $14.60 \%$ & $3.30 \%$ & $11.72 \%$ & $15.55 \%$ \\
\hline 2004Q4 & $3.85 \%$ & $5.60 \%$ & $14.40 \%$ & $3.00 \%$ & $11.64 \%$ & $15.55 \%$ \\
\hline 2005Q1 & $2.50 \%$ & $5.60 \%$ & $14.40 \%$ & $3 \%$ & $13.11 \%$ & $15.50 \%$ \\
\hline 2005Q2 & $2.40 \%$ & $5.50 \%$ & $14.30 \%$ & $3 \%$ & $13.10 \%$ & $15.40 \%$ \\
\hline 2005Q3 & $2.30 \%$ & $5.43 \%$ & $14.20 \%$ & $3 \%$ & $13 \%$ & $15.39 \%$ \\
\hline 2005Q4 & $2.00 \%$ & $5.33 \%$ & $14.20 \%$ & $3 \%$ & $13.05 \%$ & $15.39 \%$ \\
\hline 2006Q1 & $3 \%$ & $5.20 \%$ & $14 \%$ & $3 \%$ & $13 \%$ & $14.99 \%$ \\
\hline 2006Q2 & $3.10 \%$ & $4.97 \%$ & $13.90 \%$ & $3 \%$ & $12.94 \%$ & $14.97 \%$ \\
\hline 2006Q3 & $3.10 \%$ & $4.95 \%$ & $13.80 \%$ & $3 \%$ & $13 \%$ & $14.89 \%$ \\
\hline 2006Q4 & $3.20 \%$ & $4.80 \%$ & $13.80 \%$ & $3 \%$ & $13.00 \%$ & $14.66 \%$ \\
\hline $2007 Q 1$ & $3.30 \%$ & $5 \%$ & $14 \%$ & $3 \%$ & $13.98 \%$ & $13.99 \%$ \\
\hline $2007 Q 2$ & $3.39 \%$ & $5.97 \%$ & $14.20 \%$ & $2 \%$ & $14 \%$ & $13.71 \%$ \\
\hline 2007Q3 & $3.40 \%$ & $6 \%$ & $14.30 \%$ & $3.60 \%$ & $14.10 \%$ & $13.71 \%$ \\
\hline 2007Q4 & $3.41 \%$ & $6.10 \%$ & $14.30 \%$ & $3 \%$ & $14.30 \%$ & $13.65 \%$ \\
\hline 2008Q1 & $6.50 \%$ & $6.10 \%$ & $13.50 \%$ & $4.40 \%$ & $13.33 \%$ & $12 \%$ \\
\hline 2008Q2 & $6.58 \%$ & $6.31 \%$ & $13.40 \%$ & $3.50 \%$ & $13.05 \%$ & $11.53 \%$ \\
\hline 2008Q3 & $6.70 \%$ & $6.20 \%$ & $13.20 \%$ & $2.70 \%$ & $13.03 \%$ & $11.50 \%$ \\
\hline 2008Q4 & $6.80 \%$ & $5.74 \%$ & $12 \%$ & $2.70 \%$ & $13.00 \%$ & $11.30 \%$ \\
\hline 2009Q1 & $9 \%$ & $5.46 \%$ & $12.68 \%$ & $1.80 \%$ & $12.86 \%$ & $11.00 \%$ \\
\hline 2009Q2 & $10 \%$ & $4 \%$ & $12.70 \%$ & $1.90 \%$ & $12.66 \%$ & $10.90 \%$ \\
\hline 2009Q3 & $11 \%$ & $3.30 \%$ & $12.76 \%$ & $2.00 \%$ & $12.59 \%$ & $10.88 \%$ \\
\hline 2009Q4 & $11.50 \%$ & $3 \%$ & $12.80 \%$ & $3.00 \%$ & $12.77 \%$ & $10.65 \%$ \\
\hline 2010Q1 & $12.50 \%$ & $3.20 \%$ & $13.00 \%$ & $3.90 \%$ & $12.80 \%$ & $10.31 \%$ \\
\hline 2010Q2 & $13.39 \%$ & $3.37 \%$ & $13.10 \%$ & $3.20 \%$ & $12.82 \%$ & $9.75 \%$ \\
\hline 2010Q3 & $14 \%$ & $3.55 \%$ & $13.20 \%$ & $3.40 \%$ & $12.83 \%$ & $9.60 \%$ \\
\hline 2010Q4 & $14.50 \%$ & $3.55 \%$ & $13.20 \%$ & $3.40 \%$ & $12.60 \%$ & $9.30 \%$ \\
\hline $2011 \mathrm{Q} 1$ & $17.88 \%$ & $3.15 \%$ & $13.30 \%$ & $4.30 \%$ & $12.47 \%$ & $8.88 \%$ \\
\hline 2011Q2 & $18 \%$ & $2.77 \%$ & $13.30 \%$ & $3.90 \%$ & $12.40 \%$ & $8.86 \%$ \\
\hline 2011Q3 & $19.50 \%$ & $2.13 \%$ & $13.30 \%$ & $2.70 \%$ & $12.30 \%$ & $8.86 \%$ \\
\hline 2011Q4 & $20 \%$ & $1.93 \%$ & $13.31 \%$ & $1.70 \%$ & $12.25 \%$ & $8.84 \%$ \\
\hline 2012Q1 & $21.50 \%$ & $1.93 \%$ & $13.32 \%$ & $1.00 \%$ & $12.23 \%$ & $7.80 \%$ \\
\hline 2012Q2 & $23 \%$ & $1.90 \%$ & $13.35 \%$ & $2.20 \%$ & $12.23 \%$ & $7.79 \%$ \\
\hline 2012Q3 & $22.78 \%$ & $1.89 \%$ & $13.39 \%$ & $2.60 \%$ & $12.22 \%$ & $7.79 \%$ \\
\hline 2012Q4 & $22.99 \%$ & $1.88 \%$ & $13.40 \%$ & $2.50 \%$ & $12.22 \%$ & $7.60 \%$ \\
\hline 2013Q1 & $23 \%$ & $1.70 \%$ & $13.40 \%$ & $3 \%$ & $12.21 \%$ & $7.43 \%$ \\
\hline
\end{tabular}

